\title{
$\boldsymbol{\nabla}$ Artikkeli
}

\section{Tukea journalististen valokuvien tulkintaan}

\section{Ehdotus medialukutaitoa edistävästä genremallista}

\begin{abstract}
Genren käsite on osoittautunut hedelmälliseksi mediakasvatuksessa, sillä sen avulla voidaan yhdistää mediaesityksen sisällön, tuotannon ja vastaanoton näkökulmat. Genreajattelun tuominen esimerkiksi peruskouluihin edellyttää etenkin luovaan tekemiseen sitoutuvassa opetuksessa sitä, että työskentelyn lähtökohdaksi on olemassa oppilaille tuttu genre tai edes jonkinlainen alustava tyypittely. Aiemmin luodut genreytykset voivat tukea tulkintaa myös kuva-analyysiin perustuvassa opetuksessa, jonka haasteeksi muodostuvat kuitenkin ristiriitaiset genrekuvailut. Artikkeli perustuu design-tutkimukseen, jossa suunnitellaan konstruktiiviseen oppimiseen soveltuva journalististen valokuvien genreytysmalli itseopiskeluun ja koulukäyttöön. Genre voidaan ajatella tulkintakehykseksi ja siten työkaluksi. Genret voivat auttaa oppijaa suuntaamaan huomiota valokuvan tulkinnassa. Journalististen valokuvien erilaisten funktioiden pohjalta konstruoidaan neljä genreä, joita kehitetään edelleen dokumentaarisen elokuvan genretutkimuksessa ilmennyttä moodiajattelua soveltaen. Artikkelin tavoitteena on medialukutaidon edistäminen valokuvien tulkinnassa.
\end{abstract}

AVAINSANAT: journalistinen valokuva, lehtivalokuva, tulkinta, medialukutaito, genre, moodi

edialukutaidon keskeisinä osa-alueina mainitaan usein medioiden kriittinen tulkinta ja mediakielien ymmärtäminen (esim. Potter 2004, 24-27). Mediakasvatuksessa on puolestaan korostunut mediaesitysten analysointi. David Buckingham $(2003,122)$ kritisoi tämän lähestymistavan yksipuolisuutta. Hän esittää, että oppijoille tulisi muodostua laajempi ymmärrys medioiden toiminnasta ja ehdottaa luovan tekemisen sisällyttämistä mediakasvatukseen. (Myös Kupiainen \& Sintonen 2009, 128-141). Esimerkiksi luova imitointi, jossa mediateoksia matkitaan kuviteltuja markkinoita varten, voi tuottaa oivalluksia teosten kielellisten konventioiden lisäksi esimerkiksi instituutioiden rajoitteista, kuten luovuuden ja voiton tuottamisen välisistä jännitteistä. Tällainen työskentely vaatii lähtö- tai kiintopisteeksi oppijoille tutun konvention, kuten genren eli lajityypin ${ }^{1}$ tai edes jonkinlaisen alustavan tyypittelyn. Genreistä voi saada tukea tulkintaan myös kuva-analyysiin perustuvassa opetuksessa. (Ks. Buckingham 2003, 134-137.) 
Tämä artikkeli on design-tutkimus, jossa suunnitellaan medialukutaidon edistämiseksi ehdotus journalististen valokuvien (ns. lehtivalokuvien) tulkintaa tukevasta ja konstruktivistiseen oppimiseen soveltuvasta tyypittelystä tai genremallista. Designtutkimuksissa on suunniteltu etenkin oppimisympäristöjä mutta myös oppimateriaaleja ja luentoja. (Ks. Heikkinen ym. 2006, 67-76; Mayer 1999.) Keskityn medialukutaidon aspekteista mediaesitysten eli valokuvien tulkintaan (eri aspektista ks. Kupiainen \& Sintonen 2009, 101-108). Rakennan genremallia eritoten mediakasvatuksen käsitteellisen lähestymistavan pohjalta, mikä tarkoittaa tässä, että suunnittelen itseopiskelu- ja koulukäyttöä varten eräänlaisia käyttötermejä tai työkalugenrejä, jotka auttavat purkamaan valokuviin liittyviä tulkinta-asemia joko opettajan avustuksella tai itsenäisesti. (Ks. emt., 99.)

Kun valokuvauksessa on vältetty puhetta genrestä (Pienimäki 2011, 151-152), voidaan kysyä, tarvitaanko käsitettä valokuvaopetuksessakaan. Mediakasvatuksessa genreajattelu on kuitenkin osoittautunut hedelmälliseksi, sillä se voi yhdistää monipuolisesti mediaesityksen sisällön, tuotannon ja vastaanoton (tai kulutuksen) näkökulmat (Herkman 2007, 108). Vaikka valokuvatutkimuksissa ilmenee ajoittain tyypittelyitä ja genrekysymyksiin liittyviä hajanaisia mainintoja (esim. Bate 2009; Bright 2005; Salo 2000), niissä ei ole syvennytty esimerkiksi siihen, millaisin eri tavoin genren käsitettä on käytetty valokuvatutkimuksissa ja -käytännöissä, miten genreiksi kutsutut kategoriat on tuotettu, keitä nämä tyypittelyt palvelevat ja onko kaikkia joskus genreiksi sanottuja kategorioita edes mielekästä kutsua sellaisiksi. Genren käsitteelle ei ole edes vakiintunut yhtä käyttötapaa. Kaksi keskeisintä eksplikoimatta jäänyttä valokuvan genren käsitteellistystä ovat aihe- eli semanttinen luokittelu (esim. Bate 2009) ja käytäntö- tai käyttötarkoitusperustainen tyypittely (esim. Reaves 1995; Salo 2000). Toisinaan nämä käyttötavat ovat yhdistyneet. Esimerkiksi valokuvataide on ajateltu genreksi, jonka alatyypeiksi on esitetty pääasiassa aiheluokkia (esim. Bright 2005).

Jos valokuvauksessa genreiksi ymmärretään aiheluokat (esim. maisema-, urheilu-, alaston-, katuvalokuvat), on niitä lähes loputtomasti, jolloin genren käsite menettää voimansa kategorisoinnin välineenä (Pienimäki 2011, 156). Rick Altman (2002, 113-114) kirjoittaa, että semanttisen luokittelun etuna on genrejen helppo tunnistettavuus, laaja yleistettävyys ja yleinen konsensus. Hän kuitenkin kritisoi, ettei tällaisella luokittelulla päästä juuri teosten nimeämistä edemmäksi. Lisäksi jos vain osa valokuva-aiheista korotetaan genreiksi, aiheet tulevat arvotetuiksi. Jos valitaan vaikkapa valokuvakirjallisuudessa genreiksi jo mainitut, suositut valokuva-aiheet, on kysyttävä, ketä tämä palvelee tai kenen historiaa kirjoitetaan. Seurauksena voi olla esimerkiksi se, että naiskuvaajien, vähemmistöjen tai amatöörien suosimat aiheet ohitetaan. Jos aiheluokat käsitetään genreiksi, vaikeutuu valokuvien, niiden tuotannon ja vastaanoton kolmiyhteyden tarkastelu mediakasvatuksessa. Esimerkiksi puhuttaessa maisemavalokuvista luokkana on haastavaa huomioida valokuvien yhteydet niiden tuotantoon ja vastaanottoon, sillä näitä valokuvia voidaan esittää niin journalismissa, mainonnassa kuin taiteessa. (Ks. lisää valokuvien genreytyksen mahdollisuuksista ja ongelmista: Pienimäki 2011.)

Tässä artikkelissa ymmärrän genreksi tietyn yhteiskunnallisen käytännön (esim. journalismin) sisällä tuotetut ja/tai esitetyt sekä vastaanotetut, tiettyjä sosiokulttuu- 
risia tarkoituksia (esim. uutisointia, kuvittamista) varten ilmenevät valokuvat (myös emt., 152). Eri käytännöissä kohdattuihin valokuviin voi kiinnittyä erilaisia odotuksia ja uskomuksia, jotka voivat suunnata tulkintaa. Ymmärrän siten yhdeksi valokuvan päägenreksi journalistisen valokuvan, joka viittaa niin aikakaus-, sanoma- kuin verkkolehdissä journalistisessa tarkoituksessa esitettävään valokuvaan ja jota on yleensä kutsuttu lehti(valo)kuvaksi (esim. Heikkilä 2006; Männistö 1999). Tässä tekstissä puhun vain valokuvista, en kaikesta journalismissa käytetystä visuaalisesta materiaalista, johon viitataan termillä kuvajournalismi tai visuaalinen journalismi (ks. Brusila 1997, 19; Mäenpää 2008, 50). Journalistisen valokuvan käsitän otokseksi, joka kytkeytyy ajankohtaisena ja faktapohjaisena esitettävään kirjoitukseen (journalismin määrittely ks. Kuutti 2006, 73). Vaikka journalistinen valokuva on usein ajankohtainen ja dokumentaarinen otos, se voi olla myös kuvitteellinen tai metaforinen. Valokuvasta tekee journalistisen otoksen konteksti tai käytäntö ja kuvan funktio. Journalistinen valokuva on näin ollen kuvaa laveampi kokonaisuus (ks. Männistö 1999, 160). Aiemmassa tutkimuksessa journalistista valokuvaa on usein avattu suhteessa kirjoitettuun tekstiin (esim. Heikkilä 2006; Männistö 1999). Sitä vastoin valokuvien tyypittelyistä on niukasti tieteellistä tutkimusta. Suunnitellessani työkalugenrejä päähuomioni kohdistuukin journalististen valokuvien sisältöön, jonka lisäksi olen tarkkaillut taittoa, kuvatekstejä ja lehtijuttujen otsikointia.

Työkalugenrejen avulla pyrin valaisemaan sitä, millaisia tulkinta-asemia journalistiset kuvat ehdottavat (ks. Ridell 2006, 210-211). Artikkelista rajautuu pois kysymys siitä, miten ihmiset viime kädessä tulkitsevat valokuvia. Genreytykseni teoreettisena lähtökohtana toimii tulkintakehysajattelu (framing). Frame-käsitteestä on sosiologissa yhteyksissä puhunut Ervin Goffman (1974), mutta käsite on sittemmin kulkeutunut viestinnän tutkimukseen. Erkki Karvosen (2000, 78-82) mukaan kehyksen käsite sopii tutkijoiden lisäksi opiskelijoille lähtökohdaksi niin journalististen tekstien tuottamisen kuin vastaanoton analyysiin. Kehysajattelun mukaan esimerkiksi "toimittajat organisoivat informaation tulvaa sovittamalla siihen nopeasti ja rutiininomaisesti tiettyjä kehyksiä" (emt., 78). Kehystäminen helpottaa lukijoita hahmottamaan käsiteltävää asiaa. Toisaalta se on valikoivaa kontekstualisointia, jolla voidaan tiedostaen tai tiedostamatta suostutella lukijoita tiettyyn tulkintaan. Kehystys merkitsee myös, että "yksittäinen asia voidaan ympäröidä vaihtoehtoisesti erilaisilla kehyksillä, jolloin sen luonne määrittyy erilaiseksi" (emt., 78). Käsitän, että kehysanalyysissa on kyse merkitysten rakentumisen tarkastelusta, eikä tavoitteena ole osoittaa, että jokin kehys on oikea tai väärä.

Karvonen (emt., 83) kirjoittaa, että genren käsitettä voidaan käyttää melko samaan tapaan kuin frame-käsitettä. Kun rakennan journalistisia valokuvagenrejä, muokkaan niistä tulkintakehyksiä, jotka auttavat käsittämään, miten tarkastelun kohteena oleva asia on esimerkiksi visuaalisesti kehystetty. Ideana työkalugenrejen opetuskäytössä, esimerkiksi kuva-analyysissa, on, että oppija peilaa tulkittavaa valokuvaa tulkintakehyksinä toimiviin genreihin. Tämä reflektointi voi tuottaa oivalluksia esimerkiksi siitä, millaisia valokuvaustyylejä tai -periaatteita tulkittavassa otoksessa on käytetty ja millaisiin merkityksenantoihin katsojaa suostutellaan näillä valinnoilla ja mitä kriittisiä piirteitä näihin kehystyksiin voi liittyä. Tavoitteena ei ole saada tulkittavaa valokuvaa 
nimetyksi tai määritetyksi johonkin genreen kuuluvaksi. Työkalugenret toimivat konstruktivistisen oppimisen apuvälineinä tarjoten vinkkejä siitä, mitä oppija voi tarkata yksittäisessä valokuvassa ja mitä tältä pohjalta voisi miettiä. (Pienimäki 2011, 167-168.) Niitä voi myös käyttää lähtökohtina luovaan tekemiseen perustuvassa opetuksessa.

Konstruktiivista oppimista ilmenee, kun oppija aktiivisesti rakentaa annetusta informaatiosta omaa tietoa luomalla itselleen tolkullisia sisäisiä malleja tai representaatiota, joita hän voi soveltaa myöhemmissä ongelmanratkaisuissa. Oppimateriaali tukee konstruktiivista oppimista, kun siinä keskitytään olennaiseen ja tuotetaan ymmärrettävä rakenne oppijan oman mallin tueksi. (Mayer 1999, 143-154.) Jotta työkalugenret tukisivat konstruktiivista oppimista, on tärkeää, ettei niitä ole liikaa ja että niissä on selkeä rakenne. Tässä artikkelissa suunnitellut genret ovatkin ideaalityyppejä tai yleistyksiä, joita oppija voi hyödyntää mentaalisten malliensa lähtökohtina. Tästä tosin seuraa, että tulkittavassa valokuvassa voi olla parinkin työkalugenren piirteitä ja siten oppija voi peilata samaa kuvaa useampaan genreen. Työkalugenret on suunniteltu kirjallisuusvetoisesti mutta vuoropuhelussa nykykulttuurin journalististen valokuvien kanssa.

Sitä, millä kriteereillä voidaan muokata nykyisiä genrejä tulkintakehyksiksi ja rakentaa tyystin uusia työkalugenrejä, frame-ajattelu ei tosin kerro. Muissa medioissa genrejä on luonnehdittu usein semanttis-syntaktisesti, esteettisesti, ideologisesti sekä ritualistisen ja historiallisen käytön pohjalta (ks. Altman 2002, Feuer 1987). Nämä lähestymistavat eivät sovellu varsinkaan uusien tyyppien rakentamiseen, sillä niihin sisältyy oletus, että genrejä on jo olemassa. Niitä voi toki käyttää jo syntyneiden genrejen kuvailussa. (Ks. Pienimäki 2011.) Genreytyksillä pyrin siis avaamaan valokuvien esittämiä keskeisiä tulkinta-asemia. Tämän lisäksi genre-erotteluissa ja -kuvailuissa on mahdollista käyttää kriteereinä valokuviin ja niiden merkityksenantoon liittyviä kriittisiä tekijöitä; suunnitella genrestä siis työkalu kriittiseen tulkintaan (emt., 168-170)2 Työkalugenret auttavat tajuamaan esimerkiksi valokuvaustapahtumaan liittyvää vallankäyttöä ja sitä, miten tietoa ja dokumentaarisuutta tuotetaan. Aloitan silti tarkastelemalla valokuvan funktiota, sillä se on keskeinen tulkinta-asemaa luova tekijä. Tältä pohjalta syntyneitä neljää työkalugenreä kehitän ammentamalla journalismin tutkimuksesta ja varsinkin elokuvatutkija Bill Nicholsin (2001; 1991) kuvailemista moodeista, jotka ovat retorisia, eettisiä ja/tai tietoteoreettisia lähestymistapoja. Artikkelin lopussa kokoan työkalugenrejen pääpiirteet taulukkoon.

\section{Journalistisen valokuvan alatyypit funktion perusteella}

Aiemmassa tutkimuksessa journalistisen valokuvan alatyyppejä on määritelty kirjavasti. Esimerkiksi Paul Lester (1991, 6-28) nimeää valokuvajournalistisiksi toimeksiannoiksi uutis-, feature-, urheilu-, muotokuva- ja kuvitusvalokuvat sekä kuvakertomukset. Edgar Shaohua Huang $(2001,155)$ esittää puolestaan jaottelua: kovat uutiskuvat, feature-kuvat ja kuvitusvalokuvat. (Myös esim. Kobré 2008; Miettinen 1984, 185-204; Mäenpää 2008; Salo 2000). Seuraavaksi kokoan sosiokulttuuristen käyttötarkoitusten eli funktioiden pohjalta journalististen valokuvien perustavat työkalugenret. 
Perinteisimpiä valokuvan journalistisia funktioita on uutisointi (esim. Salo 2000). Stuart Hallin $(1984,174)$ mukaan uutisvalokuvan (toimituksellisen valokuvan) on täytettävä kolme kriteeriä: (1) valokuva liittyy tapahtumaan, sattumaan tai tapaukseen, joka on (2) äskettäinen, ja (3) tapahtuman tai henkilön on saavutettava uutisarvo eli täytettävä uutiskriteerit. Tutkimuksissa uutiskriteerejä on määritelty monella tapaa (esim. Kuutti 2006, 243-244). Paul Brighton ja Dennis Foy (2007, 25-29) ehdottavat nykykriteereiksi, että raportoitava asia on (1) asiaankuuluva eli vastaanottajalle merkityksellinen (relevance), (2) ajankohtainen (topicality), (3) istuu muuhun kokonaisuuteen (composition), (4) sellaista jonka "vastaanottaja odottaa kerrottavan" (expectation), (5) epätavallinen (unusualness), (6) esittämisen arvoista (worth) ja (7) ulkoisista vaikutteista (esim. korruptiosta) puhdas (external influences). Uutisen määritelmä avaa mielestäni myös uutisvalokuvaa: "Journalistinen genre eli juttu- tai ohjelmatyyppi, jolle on tyypillistä uuden, yllättävän ja merkittävän tiedon kertominen äskettäin tapahtuneesta tai tietoon saadusta, yleisesti kiinnostavasta asiasta." (Kuutti 2006, 242).

Kun ammattilaiskuvajournalistit vaativat uutisvalokuvalta oleellisesti faktapohjaisuutta ja objektiivisuutta, toiseen äärilaitaan he asettavat kuvitusvalokuvat ${ }^{3}$ (Mäenpää 2008). Kuvituskuville ei yleensä anneta ajankohtaisen raportoinnin tehtävää (esim. Salo 2000, 156). Ne eivät täytäkään kaikkia uutiskriteereitä ja ne ymmärretään yleensä uutisarvottomiksi. Niiden tarkoitus on mielikuvia luomalla avoimesti, jopa korostuneesti havainnollistaa asioita ja/tai toimia visuaalisina houkuttimina tai katseen vangitsijoina. Kuvitusvalokuva rakennetaan monesti idean pohjalta ja se voi olla esimerkiksi kuvamontaasi tai lavastettu, metaforinen otos. Niitä käytetään eritoten, kun aihe on dokumentaarisesti esitettäväksi arkaluontoinen (esim. huumeiden käyttö) tai vaikeasti visualisoitavissa (esim. talous). Kun inmisiä esiintyy kuvituskuvissa, he ovat yleensä nimettömiä. (Kobré 2008, 334-351; Evans 1987, 287-322; Salo 2000, 155-165.) Kuvitusvalokuvien määrittelyissä on tosin eroja. Esimerkiksi Christopher R. Harris (2002, 112-117) ymmärtää kuvitusvalokuviksi vain ilmiselvästi rakennetut, eidokumentaariset valokuvat, mutta ainakin Suomessa dokumentaarisia uutisvalokuvia käytetään uudelleen havainnollistamistarkoituksissa. Kuvitusvalokuvat ovat siis fiktiivisiä tai dokumentaarisia, mutta vaikka ne on otettu dokumentaarikuvauksen periaattein, niiden tehtävänä on yhä mielikuvin havainnollistaa asioita. Tärkeintä lieneekin, että oppija tunnistaa kuvituskuvat muista journalistisista otoksista eroavan funktionsa tähden. Lehdissä monesti vältellään dokumentaaristen ja dokudraamojen eli lavastettujen dokumentaarisilta näyttävien kuvitusvalokuvien käyttöä, sillä niitä voi erehtyä pitämään uutisarvoisina otoksina (Kobré 2008, 339).

Uutis- ja kuvitusvalokuvista on monesti erotettu valokuvat, joiden tarkoituksena on identifioida ja luonnehtia ihmisiä. Näitä usein henkilövalokuviksi sanottuja otoksia käytetään varsinkin haastatteluissa. Henkilövalokuvauksessa tavoitellaan pitkälti samaa kuin muotokuvauksessa. Molemmissa pyritään kuvattavan ulkoisuuden ilmentämisen ohella luonnehtimaan hänen psyykeään ja identiteettiään: kertomaan jotakin olennaista tai tyypillistä mallin eleistä, olemuksesta, ajatuksista, tunteista, sisäisyydestä, yksilöllisyydestä, ammatista ja/tai asemasta. (Esim. Freeland 2007, 98-100; Lester 1991, 17-20; Miettinen 1984, 196). Vaikka henkilövalokuvia sanotaan joskus 
etenkin englanniksi journalistisiksi muotokuviksi, muotokuva- ja henkilökuvat ovat mielestäni eri tyyppejä (myös Brusila 1997, 97). Muotokuvat perinteisesti ylläpitävät tai vahvistavat mallin asemaa tai valtaa (esim. presidentin kuva viraston seinällä), kun taas henkilökuvia käytetään epävirallisemmissa yhteyksissä. Muotokuvaan verrattuna henkilövalokuvassa ihmisen luonnehdinta on ohuempaa ja vähemmän ylevöitettyä. (Ks. esim. Freeland 2007; Palin 1993.) Henkilökuvan malli ei aina voi osallistua julkaistavan kuvan valintaan, eikä hän yleensä omista valokuvaa - toisin kuin muotokuvauksessa. Näitä kategorioita erottavat siis vallankäytöt, käyttöyhteydet ja omistuskuviot. ${ }^{4}$

Henkilövalokuvien kategorisoinnissa on vaihtelua. Esimerkiksi Shiela Reaves (1994) sijoittaa henkilökuvat feature-kategoriaan (myös Huang 2001; Mäenpää 2008). Hän $(1994,709)$ kuvailee feature-valokuvien sisältävän esimerkiksi ajattomia ilmiö- ja henkilökuvia, kuten säätilamuutoksista kertovia maisemakuvia ja lasten, pariskuntien tai vanhusten arkea esittäviä otoksia. Reavesin (1994, 708-709) mukaan sanomalehtien toimittajat vaikuttavat erottavan featuret uutisista ja kuvituksista, mutta asiasta on kiistelty (myös Newton 2001, 5). Mainitut kuvaesimerkit voivat tosin olla myös uutisarvoisia valokuvia, kuten otos juuri sattuneesta tuhoa tehneestä sadekuurosta (esim. Harris 2002, 97). Toisaalta jos maisemavalokuvalla ei ole uutisarvoa, se esitetään usein mielikuvatehtävässä. Kuvien funktion näkökulmasta featurea ei siis ole perusteltua ottaa työkalugenreksi.

Silloinkin kun henkilövalokuva on mainittu itsenäisenä genrenä, sen avaukset ovat olleet vaillinaisia. Epäselvää on etenkin, mikä erottaa henkilökuvat ihmisaiheisista uutiskuvista. Nähdäkseni henkilökuvina on implisiittisesti pidetty varsinkin sellaisia otoksia, joissa erityisesti luonnehditaan kuvattavaa, jonka kanssa jopa usein sovitaan tietty kuvaushetki. Vaikka uutisvalokuvat voivat kertoa jotakin ihmisistä, päähuomio on yleensä tapahtumissa, joihin henkilö liittyy. Tämä tarkoittaa semioottisesti ilmaisten, että näissä kategorioissa merkkien hierarkia eroaa. Henkilövalokuvissa ihminen on kiistatta päämerkki ja muut merkit ovat alisteisia sille. Niissä näkyvät esineet, paikka, vaatteet, valaistus ynnä muu ovat yleensä tarkemmin harkittuja kuin uutiskuvissa. Esineiden ynnä muun tehtävänä on osaltaan luonnehtia ihmistä tai kertoa hänen tarinaansa (esim. Kobré 2008, 87-93; Freeland 2007, 98; Lester 1991, 18). Uutiskuvissa ne ovat sattumanvaraisempia, tosin ne on silloinkin hyväksytty osaksi julkaistun valokuvan merkityksiä.

Lehdissä esiintyy tosin myös ihmisaiheisia valokuvia, jotka eivät luonnehdi ihmisiä, mutta jotka eivät myöskään ole uutiskuvia. Hall $(1984,185)$ esittää, että passikuvien kokoisten ja kaltaisten otosten tehtävänä lehdissä on todistelu: tämä on se mies, josta puhumme, hän on todella olemassa. David Bate $(2009,64-81)$ laskee nämä otokset sekä muotokuva- ja henkilövalokuvat yhdeksi tyypiksi. Funktion pohjalta passikuvat ja senkaltaiset kuvat on silti perusteltua käsittää itsenäiseksi tyypiksi, jonka tehtäväksi käsitän identifioimisen: ilmentää tai muistuttaa vain, miltä joku henkilö näyttää ulkoisesti. John S. Knox (2009) on tutkinut australialaisen Sydney Morning Herald online -sanomalehden pienikokoisia kasvokuvia, joita hän kutsuu nimellä thumbnail faces. Tällaisia otoksia ja myös esimerkiksi poliisien pidätyskuvia on kutsuttu nimellä mug shots (Bate 2009, 69-71; Harris 2002, 114). Suomessa vastaavia kuvia on kutsuttu 
tunnistevalokuviksi (Tuori 2001). Nimi sopii mielestäni hyvin tälle passikuvia muistuttavalle tyypille, sillä se luo mielleyhtymän valokuvien käyttötarkoituksesta.

Knoxin (2009, 177-180, 185) mukaan thumbnail-kuvat eivät juuri lisää uutisjutun sisältöä, eikä niillä ole todistearvoa. Niiden tarkoituksena on personoida lehden kertomukset ja siten esimerkiksi saada yleisöt kiinnostumaan jutuista. Tunnistekuviin voi liittyä myös varmistus: tiedämme, miltä näyttää joku, joka sanoi tai teki näin. Ne toimivat siis sosiaalisena kontrollointina. (Myös Tuori 2001, 54-55.) Painetuissa sanomalehdissä nämä otokset ovat usein pienikokoisia, lähes silmien tasolta kuvattuja lähikuvia (myös Knox 2009, 169), mutta aikakauslehdissä ne ovat toisinaan isompia. Nämä kuvat ovat niukalti tyyliteltyjä (Harris 2002, 114), esimerkiksi kuvan taka-ala voi olla sekavahko tai yksivärinen, tai kuva on syvätty. Niihin ei aina liity kuvatekstiä. Käsitän tunnistekuvat Knoxin esitystä laveammaksi tyypiksi, sillä lasken niihin samantyyppiset esimerkiksi esineitä, eläimiä ja paikkoja identifioivat valokuvat, kuten pelkistetyn valokuvan rakennuksesta, jossa toimii jutussa käsitelty yritys. Näillä valokuvilla saattaa joskus olla uutisarvo, vaikkapa kun kuvassa on markkinoille tullut lapsille vaaraksi oleva lelu. Esine- tai paikkakuva voi toisinaan olla todisteenkaltainen dokumentti esimerkiksi esittäessään rikosvälineen tai -paikan. ${ }^{5}$

\section{Moodiajattelu journalistisen valokuvan työkalugenrejen suunnitteluun}

Journalististen valokuvien eriävien käyttötarkoitusten perusteella muodostuvat siis uutis-, kuvitus-, henkilö- ja tunnistevalokuvien työkalugenret. Seuraavaksi kehitän edellä kuvailtuja tyyppejä hyödyntäen moodiajattelua, jota on käytetty genrejen rinnalla. Eritoten elokuvatutkija Bill Nicholsin (2001; 1991) moodit purkavat journalistisia valokuvia. Ne liittyvät dokumentaariseen elokuvaan, mutta niissä on rajankäyntiä fiktiivisten teosten kanssa. Vastaavanlaista vuorovaikutusta esiintyy journalistisissa valokuvissa. Nicholsin moodijäsennys on antoisa näkökulma valokuvan työkalugenrejen suunnitteluun myös siksi, että moodit eroavat toisistaan osin elokuvan kuvaustilanteisiin liittyvien tapojen ja sääntöjen pohjalta. Ne avaavat kriittisen katseen myös valokuvaukseen liittyviin etenkin valokuvaaja-kuvattava-valtasuhteisiin.

Nicholsin $(2001,99)$ mukaan voidaan tunnistaa kuusi representoimisen moodia: runollinen (poetic), selittävä (expository), havainnoiva (observational), osallistava (participatory), refleksiivinen (reflexive) ja performatiivinen (performative). (Moodikritiikistä esim. Helke 2006, 56-57). Hän (2001, 99) luonnehtii, että moodit ovat löysiä kehyksiä, joiden puitteissa tekijät voivat toimia ja jotka tuottavat spesifejä odotuksia, jotka katsojien ennakoidaan täyttävän. Hänen näkemyksiään reflektoiva Susanna Helke $(2006,15)$ esittää moodien olevan "lähestymissäännöiksi kiteytyneitä näkemyksiä siitä, miten dokumentaareja pitää tehdä". Helke (emt., 55) erittelee, että moodiin voi liittyä tyyli(suunta), mutta se ei ole synonyymi tyylille. Moodi voi ilmaista tekijän työtapaan kätkeytyviä esteettisiä ja eettisiä pyrkimyksiä ja ihanteita, mutta se ei ole sama kuin työtapa. Hänen mukaansa Nicholsin moodeissa painottuu tietoteoreettinen kysymys siitä, miten tietoa voidaan saada todellisuudesta; millaisin keinoin his- 
toriallista, yhteiskunnallista tai sosiaalista todellisuutta voidaan lähestyä, tavoittaa tai paljastaa. Moodit eroavat siis siinä suhteessa, miten dokumentaarisuutta ajatellaan voitavan tuottaa.

Nicholsin (2001; 1991) ja Helken (2006) pohjalta ajattelen, että valokuvauksessa moodi voi tarkoittaa tekijän tai aikakauden retorista, eettistä ja/tai tietoteoreettista lähestymistapaa, johon voi kiinnittyä varsinkin valokuvausperiaatteita ja -tyylejä. Seuraavaksi kehitän työkalugenrejä siten, että ne auttavat tajuamaan journalistisiin valokuvien kytkeytyviä mielestäni keskeisimpiä moodeja ja niiden kriittisiä piirteitä. Designotteen vuoksi en tässä artikkelissa kuitenkaan keskity vertailemaan elokuvan ja valokuvan moodeja, vaan fokus on valokuvagenrejen luomisessa. Design-tutkimus ei pyri sellaisiin tuloksiin, joita voi arvioida kuten vaikkapa perinteistä empiiristä tutkimusta, Daniel C. Edelson (2002, 117-118) kirjoittaa ja korostaa tärkeimpinä arviointikriteereinä designin uutuutta ja käytettävyyttä. Genreytysehdotustani onkin oleellista vielä testata autenttisissa olosuhteissa, kuten kouluissa.

\section{Havainnoivaa moodia edustavat uutisvalokuvat}

Nicholsin esittelemistä elokuvamoodeista uutisvalokuvissa ilmenevät eritoten havainnoiva ja osallistava. ${ }^{6}$ Keskityn tässä artikkelissa näihin kahteen myös siksi, että ne olennaisesti luovat kuvankatsojalle tulkinta-asemaa. Havainnoivaan moodiin keskeisesti kiinnittyvä tyylisuunta on direct cinema ja osallistavaan cinéma vérité (Helke 2006, 61). Helken (emt., 63) mukaan "Direct cinemassa sosiaalinen ja yhteiskunnallinen todellisuus ilmenee tapahtumina. Tekijät etsivät tapahtumia, jotka syntyivät ja tapahtuivat kuvausryhmän niihin vaikuttamatta. He valitsivat aiheikseen ilmiöitä, jotka itsessään olivat eräänlaisia julkisia esityksiä, kuten poliittisia draamoja tai rockmuusikoiden kiertueita." Nichols (2001, 109-114) kuvailee havainnoivaa moodia vastaavasti: elokuvantekijä keskittyy preesensissä tapahtuvaan siihen avoimesti puuttumatta. Elokuvan on näytettävä samanlaiselta kuin, jos kamera ei olisi läsnä tilanteessa. Samansuuntaisesti Kenneth Kobré $(2008,21)$ esittää, että valokuvajournalistin on tallennettava inmiset mahdollisimman tietämättöminä kuvauksesta, jotta tavoitetaan todellisia emootioita (myös Rosler 2000, 19). Piilokameran kaltaista, ei tosin suoranaisesti piilokamerakuvausta, ilmenee osassa nykykulttuurin uutiskuviakin.

Havainnoivaan moodiin liittyy siis eräänlainen puuttumattomuuden kuvausperiaate, jonka mukaisissa uutiskuvissa fokusoidaan usein direct cineman tapaan tietynlaisiin tapahtumiin. Tätä kuvausperiaatetta käytettäessä kuvataan usein julkisesti näyttäviä tai yhteiskunnallisesti huomattavia tapahtumia, kuten katastrofeja, avajaisia tai politiikan tilanteita (yleensä ei kuvata esim. tavallisten ihmisten arkisia hetkiä). Tähän tyyliin on luonnehdittu myös niin sanottuja kovia uutiskirjoituksia (esim. Tuchman 1978 , 47, 52). Risto Kuneliuksen $(1993,34)$ mukaan kovien uutisten sisältöä ovat yhteiskunnassa tärkeiksi ja yleisesti merkittäviksi käsitetyt asiat. ${ }^{7}$ Nämä uutiset käsittelevät usein ennakoimattomia tilanteita (kuten tulipaloa) tai ajankohtaisia mutta ennakolta tiedettyjä, huomattavia tapahtumia (kuten vaalit). (Tuchman 1978, 52; Bell 1991, 14.) 
Ennakoimattomia tilanteita esittäviä uutisvalokuvia on joskus kutsuttu englanniksi spot news photos (esim. Kobre 2008, 26-47; Lester 1991, 7-8) ja ennakoituihin tilanteisiin liittyviä valokuvia puolestaan nimellä general news photos (esim. Kobre 2008, 48-63; Lester 1991, 8; vrt. Harris 2002, 96-98). Uutistilanteen ennakoimattomuus tai ennakoitavuus ei sinällään tuota eriäviä tulkinta-asemia, joten näiden kategorioiden eriyttämisestä eri työkalugenreiksi ei ole erityistä hyötyä. Puuttumattomuusperiaatteen mukaiset uutisvalokuvat esiintyvät nähdäkseni usein kovien uutiskirjoitusten rinnalla ja tässä kontekstissa valokuvien sisällöt vahvistuvat entisestään tärkeinä ja yleisesti merkittävinä.

Kuneliuksen (1993, 34-36) mukaan kovaa uutiskirjoitusta ei määritä uutisen sisältö, vaan rajoittuminen faktojen esittämiseen. Kova uutinen tarjoaa etäistä tietoa ja hylkää yksityiset intressit, mielipiteet ja asiaankuulumattoman subjektiivisuuden (Poecke 1989, 16). Edellä sanottu pätee pitkälti havainnoivan moodin mukaisiin uutiskuviin, joita voisi kenties sanoa koviksi uutisvalokuviksi (ks. esim. Reaves 1995; Loosley 1970, 26-39). Vastaavasti Jorma Miettinen $(1984,185)$ esittää yhdeksi journalistisen valokuvan tyypiksi tapahtumakuvaa, jonka tulkitsen vastaavan havainnoivan moodin uutisvalokuvaa. Hänen mukaansa nämä otokset vangitsevat tapahtuman keskeiset tai kiintoisimmat piirteet; ne tiivistävät tilanteen, tunnelman tai tapahtuman keskipisteen. Nämä valokuvat voivat myös esittää tapahtuman keskeiset toimijat ja ne ovat yleensä visuaalisesti niukalti tyyliteltyjä. Lisäksi pyrkimyksenä on tavoittaa "ratkaiseva hetki" (esim. Kobre 2008,18 ). Näiden uutiskuvien tehtävänä on siis olla faktuaalisia. Kuvatoimittajat sallivatkin niiden digitaalista manipulointia vähiten (Reaves 1995, 713).

\section{Osallistavan moodin mukaiset uutisvalokuvat sekä feature-valokuvat}

Kunelius $(1993,34)$ kirjoittaa pehmeiden uutisten olevan puolestaan kiinnostavia ja merkityksiltään erityisiä tai yksityisiä. ${ }^{8}$ Käytännössä sama uutinen voi ilmetä tärkeänä (kovana) että kiinnostavana (pehmeänä). Erottelu on siis analyyttinen (Boczkowski 2009, 99). Pehmeät uutiset, kuten juttu iloisesti tervehtivästä bussinkuljettajasta, eivät välttämättä ole erityisen ajankohtaisia (Tuchman 1978, 48, 51). Ne tuodaan silti esille uutisina. Lehdissä esiintyy vastaavanlaisia uutisvalokuvia, joiden annetaan ymmärtää olevan kiinnostavia ja joilla on lähinnä lievä uutisarvo. Nämä uutiskuvat voivat esittää esimerkiksi yhden tapauksen tai yksityiskohdan uutisesta tai kertoa laaja-alaisesta ja/tai pitkäkestoisesta ilmiöstä tai tapahtumasta, ilmentää tavallisten inmisten arkea mutta myös paljastaa julkkisten elämää. (Vrt. Poecke 1989, 19-20.) Ne perustuvat havainnoivaa moodia edustavista uutisvalokuvista poikkeavaan näkemykseen siitä, millaiset tapahtumat tai ilmiöt tuottavat uutisen tai millaisista asioista elämän perimmäinen luonne voidaan tavoittaa. Nämä valokuvat eivät siis välttämättä esitä aivan äskettäin sattuneita tapahtumia tai ehkäpä vain sivuavat varsinaista uutisaihetta (vrt. Hall 1984).

Edellä kuvaillut uutiskuvat ilmentävät nähdäkseni harvemmin puuttumattomuuden periaatetta (poikkeuksena paparazzi-kuvat), vaikka ne voivat näyttää sen mukaisilta. 
Näiden otosten kuvaaja on usein kanssakäymisessä kuvattavien kanssa ja siten niihin liittyy eräänlainen vuorovaikutteisuuden valokuvausperiaate, joka on Nicholsin kuvaileman osallistavan moodin keskeinen piirre. Osallistavaan moodiin liittyy epistemologinen näkemys, ettei ole olemassa absoluuttista totuutta. Jos on olemassa totuus, se ilmenee kameralle tarjoutuvan vuorovaikutustilanteen muodossa. (Nichols 2001, 115-123.) Sen sijaan että kuvaaja on "kärpänen seinällä", hänestä tulee sosiaalinen toimija (Nichols 2001, 116; myös Helke 2006, 65-66). Nicholsin (2001, 121) mukaan elokuvauksessa osallistuvan moodin yleisin muoto on haastattelu, mikä rinnastuu kuvattavien kanssa yhteistyössä toimivaan valokuvaajaan. Tämä moodi ilmenee selkeimmin poseerauksen mahdollistavassa henkilövalokuvauksessa. Poseerattuja valokuvia pidetään usein epäluonnollisempina kuin piilokameraotoksia (esim. Kobré 2008, 82; myös Newton 2001, 43) $)^{9}$. Kutsun jäljempänä eri moodeja edustavia uutiskuvia nimillä havainnoiva ja osallistava uutisvalokuva. Voisi kenties puhua myös kovasta ja pehmeästä uutiskuvasta.

Mediatalon näkökulmasta havainnoivan (kovan) uutiskuvan tuottaminen tarkoittaa, että on pikimmiten lähetettävä valokuvaaja paikalle, jossa juuri tapahtuu, tai sitten uutisvalokuva hankitaan freelancerilta, toiselta mediatalolta tai lukijoilta. Sitä vastoin osallistavan (pehmeän) uutiskuvan kohdalla toimituksessa usein pohditaan, millainen otos uutiseen tuotetaan (vrt. Bell 1991, 14; Tuchman 1978, 50-58). Osallistava kuva voidaan tuottaa uutisjutun lisäksi esimerkiksi taustajutun, ennakkouutisen tai tutkivan journalismin jutun oheen, jolloin uutiskuva saattaa liittyä varsinaiseen uutiseen vain väljästi. Ajoittain käytetty ratkaisu on, että uutista havainnollistetaan sitä sivuavalla toisella marginaalisella mutta samanaikaisella uutistapahtumalla, jolloin kuvatekstin keskeinen tehtävä on sitoa uutiskuva varsinaiseen uutiseen.

Osallistavan moodin uutiskuvia on joskus Suomessakin kutsuttu englannin sanalla feature (myös aihekuvat, ks. Miettinen 1984, 200). Myös pehmeitä uutiskirjoituksia on kutsuttu featureiksi (Tuchman 1978, 47) tai featuret on ajateltu yhdeksi pehmeiden uutisten alalajiksi (Bell 1991, 14). Feature-valokuvauksen syntyä tutkinut Andrew Mendelson (2004, 166, 168, 174) kirjoittaa, että feature-valokuvan tarkoituksena on tavoittaa ihmisluonteesta jotakin pysyvää ja ajatonta. Feature viittaa human interest -aiheisiin dokumentaarisiin valokuviin, joiden ydinajatuksen oivallus ei edellytä tekstiä ja joissa korostuu konnotatiivinen ulottuvuus. Tyypillisesti featuret ovat sympaattisia tai humoristisia otoksia lapsista tai eläimistä. Kuutti $(2006,53-54)$ kuvailee, että human interest -esitysten näkökulmassa tai tyylissä painottuu muiden muassa inhimillisyys ja elämyksellisyys ja niissä vedotaan ihmisten tunteisiin. Kobrékin (2008, 67-79) opastaa, miten löytää ajattomia ja arkipäiväisiä feature-valokuvia hiljaisia uutispäiviä varten (myös Reaves 1995, 709). Kun internetistä tekee hakuja, ilmenee, että featurekuvilla voi olla suuri tai lievä uutisarvo, mutta ne voivat olla myös uutisarvottomia. Täten havainnoivista uutiskuvista ylijäävien uutisarvoisten valokuvien kutsuminen featureiksi on ongelmallista - ja ne eivät kaiketi kaikki ole ihmisläheisiä. Feature onkin käsittääkseni moodi, jossa elämän perimmäinen luonne ajatellaan tavoitettavan esimerkiksi spontaaneista, sympaattisista sattumuksista. Tämä moodi voi ilmetä sekä havainnoivassa että osallistavassa uutisvalokuvassa. 


\section{Tyyli visuaalisena vihjeenä uutisvalokuvien totuusarvosta}

Havainnoiva moodi ei ole vain kuvausperiaate ja näkemys siitä, miten tuottaa tietoa. Dokumentaarin on myös näytettävä objektiiviselta tai autenttiselta. Nichols (1991, 127) esittää, että jos katsoja tiedostaa näkökulman, josta asiat esitetään, hän ei pidä elokuvaa enää mekaanisena kopiona tai arvovapaana historiallisen todellisuuden reproduktiona - vaikka dokumentaari vastaisi kulttuurisesti määrittynyttä objektiivisen reportaasin standardia. Nichols $(1991,127)$ korostaa, että objektiivinen tyylikin on näkökulma.

Etenkin puuttumattomuuden kuvausperiaatteella tuotettuihin uutisvalokuviin kytkeytyy nähdäkseni usein objektiivisuuden tyyli, joka tarkoittaa tietynlaista näköisyyttä (esim. värit sopivan kylläisiä, tarkennus pääkohteissa ja usein laaja syväterävyys). "Oikeanlaisesta" näköisyydestä kirjoittavat Gunther Kress ja Theo van Leeuwen (1996, 159-180) puhuessaan kuvien totuusarvosta ja -vihjeistä (modality markers): kuvan totuudellisuus ja realistisuus riippuvat sen ilmentämästä visuaalisten vihjeiden yhdistelmästä ja vihjeiden totuusarvo riippuu kontekstista. Esimerkiksi kun mainosten kokemisessa hallitsee nautittavuus, mainoskuvien värit saavat olla kylläisempiä ja värähtelevämpiä (vibrant) ollakseen vielä totuudellisempia ja realistisempia kuin luonnollisempaa ilmaisua edellyttävissä kuvissa - kuten uutisvalokuvissa. Kyse ei ole absoluuttisesta totuudesta, vaan siitä tarjotaanko esitys totena vai ei.

Visuaalisia totuusvihjeitä voivat olla myös eräät tekijät, joita Kress ja van Leeuwen eivät mainitse, kuten tietynlainen kuvaushetki. Tämän lavennuksen myötä voidaan viimeistään puhua kuvaustyylistä. Objektiivisuustyylin valokuvia katsoessa tuntuu, että valokuvaaja oli näkymätön, puolueeton sivustatarkkailija, joka vain rekisteröi näkemänsä (kuvajournalistinen tyyli ks. Kobré 2008, 21). Keskeisimpiä totuusvihjeitä tässä tyylissä on, että valokuvien perusteella näyttää, että kuvattavat eivät tiedostaneet valokuvausta. Lisäksi suositaan esimerkiksi, että valokuvaaja lähestyy pääkohdettaan sivusuunnassa vinosta kulmasta. Silloin kuvankatsojalle sanotaan: mitä näet tässä, ei kuulu meidän maailmaamme (Kress \& Leeuwen 1996, 143). Myös silmien tasolta kuvaaminen voi monesta aikuiskatsojasta tuntua läpinäkyvältä, koska se on arjesta tuttu kulma katsella toisia aikuisia. Objektiivisuustyyli on siis näkymätöntä ja etäännyttävää kerrontaa, jolla vahvistetaan tunnetta dokumentaarisen otoksen todenmukaisuudesta.

Nichols $(1991,127)$ esittää, että objektiivisuus korostaa kuvattujen tapahtumien denotatiivista ulottuvuutta mieluummin kuin subjektiivisia tai konnotatiivisia tekijöitä. Jos kuvankatsojien huomio suunnataan enemmän ilmimerkityksiin, ongelmaksi voi muodostua se, että valokuvan konnotatiiviset merkitykset erehdytään tulkitsemaan denotatiivisiksi tosiasioiksi (myös Fiske 1992, 115) ja valokuvien ilmentävät ideologiat voivat jäädä peittoon (ks. Bate 2009, 53-54). Kun objektiivisuustyyli kieltää itsensä tyylinä, sen käyttö dokumentaarisissa otoksissa voi hämärtää sitä tosiasiaa, että valokuvat ovat aina representaatioita.

Puuttumattomuuden kuvausperiaatteella otettuun uutisvalokuvaan voi liittyä myös muita kuvaustyylejä. Kun vaikkapa mielenosoitusta esittävässä kuvassa ilmenee epä- 
terävyyttä, voi epätarkkuus toimia visuaalisena vihjeenä valokuvaustilanteen aitoudesta (vrt. elokuvassa reagoiva käsivarakuvaus; ks. Reaves 1995, 708). Helke (2006, 73, 78-79) puhuukin autenttisuustyyleistä, joilla tuetaan välittömyyden ja tilanteisiin puuttumattomuuden tunnetta; vakuutetaan kuvaushetken aitous. Reaves (1995, 708) esittää Sol Worthiin ja Larry Grossiin viitaten, että luonnollisiksi ja symbolisiksi koetut tapahtumat johtavat helposti erilaisiin tulkintastrategioihin. Hän jatkaa, että kun uutisvalokuvat ovat luonnollisia, ne tulkitaan "informatiivisina" eikä "kommunikatiivisina merkityksinä". (Myös Hall 1984, 185). Objektiivisuus- ja autenttisuustyylit suostuttelevat tulkitsemaan uutisvalokuvat totuudellisina ja informatiivisina; kuvat ehdottavat siis käsittämään itsensä ikonisina indekseinä.

Pehmeissä uutisteksteissä kerronta on eloisampaa, intiimimpää, subjektiivisempaa, ylipäätään vapaampaa kuin kovissa uutisissa. (Tuchman 1978, 100-101; Poecke 1989, 16-24.) Vastaavasti osallistavissa uutisvalokuvissa kuvaustyylit ovat vapaampia. Niihin liittyy monesti tyylejä, jotka eivät kätke kuvaajan ja kuvattavan välistä vuorovaikutusta (Nichols 2001, 118). Nämä tyylit vihjannevat siitä, että kuva on pikemmin kiinnostava kuin tärkeä ja että se on totuusarvoltaan vähäisempi kuin objektiivisen tyylin otos. Toisaalta kun eritoten objektiivisuuden tyyliä voidaan käyttää myös osallistavassa uutiskuvassa, voi toisinaan olla haastavaa erottaa havainnoivan ja osallistavan moodien uutiskuvia pelkän kuvan perusteella. Havainnoivaan ja eritoten osallistuvaan uutiskuvaan voi liittyy siis monenlaisia tyylejä, joita olisikin aihetta tutkia lisää.

\section{Kaksi työkalugenreä uutisvalokuvien tulkintaan}

Medialukutaidon näkökulmasta havainnoivan ja osallistavan moodin tunnistaminen uutisvalokuvista on suotavaa. Havainnoivaan moodiin liittyvä puuttumattomuuden valokuvausperiaate voi vaikuttaa vakuuttavalta tavalta lähestyä uutistapahtumaa. Piilokameratyyppinen kuva voi kuitenkin olla enemmän kuvaajan kuin kuvattavien näkemys asiasta (Newton 2001, 43). Nichols (2001, 111) kirjoittaa, että havainnoivaan moodiin liittyy monia eettisiä seikkoja, kuten onko kyse voyeuristisesta tirkistelystä tai epäsuorasta tunkeilusta. (Myös Rosler 2000, 19-21; Newton 2001, 41.) Puuttumattomuuden periaate onkin kova kuvattavia kohtaan. Valtasuhteena on, että valokuvattavat ovat valokuvaajan (ja toimituksen) armoilla. ${ }^{10}$ Havainnoivan uutiskuvan suuren uutisarvon suhde vallankäytöllisiin aspekteihin on syytä huomata: entä jos tärkeänä, objektiivisena ilmenevä uutisvalokuva riistää valokuvattujen henkilöiden itsemääräämisoikeutta suhteessa heidän ulkoisuuteensa ja elämäänsä? Kysymys vallankäytöstä on silti kaksiteräinen miekka, sillä tämä kuvausperiaate voi myös paljastaa jopa virallisen totuuden vastaisia asioita. (Esim. Newton 2001, 40-42, 58-59; Lester 1991.) Sitä paitsi löytyykö uutiseksi käsitettävä "totuus" juuri sattuneista yhteiskunnallisesti tärkeiksi tai yleisesti merkittäviksi käsitetyistä asioista? (Myös Kunelius 1993, 42-43.) Monet kuvaajat ovat myös kyseenalaistaneet, että elämän syvin luonne voidaan paljastaa, kun kuvaaja on tilanteista ulkopuolinen. Nämä doku- 
mentaristit voivatkin elää osana yhteisöä, jota he kuvaavat (Rosler 2000, 19-20; Newton 2001, 41).

Osallistavaan moodiin liittyvä vuorovaikutteisuuden kuvausperiaate antaa malleille valtaa ja se on siten pehmeämpi heitä kohtaan. Toisaalta kun malli voi vaikuttaa valokuvansa syntyyn, voi miettiä, onko hän luonut harhauttavan esityksen vaikkapa manipuloidakseen julkista imagoaan (Newton 2001, 42). Tämä periaate jättää tosin lehtien valokuvaajille ja toimitukselle yhä paljon valtaa tuottaa kuvallisia merkityksiä. Kun tämän periaatteen mukaisissa valokuvissa tavoitellaan yhä todenkertomista, voi pohtia, onko valokuvaaja näkemystensä vahvistukseksi provosoinut esiin jotakin (ks. Helke 2006, 67). Lisäksi se missä määrin valokuvattavat voivat osallistua kuvausprosessiin voi olla eriasteista, ja raja vuorovaikutteisuuden ja puuttumattomuuden kuvausperiaatteiden välillä on liukuva. Nämä periaatteet ilmenevät myös tunnistevalokuvissa, jotka voidaan kuvata varta vasten mutta, jotka voivat myös olla vaikkapa leikattu aiemmasta havainnoivasta uutiskuvasta.

Havainnoiville ja osallistaville uutiskuville voidaan esittää monia samoja kysymyksiä: miten asiat esitetään, miksi otos on julkaistu? On silti asioita, joita osallistavien uutiskuvien kohdalla on erityisesti tarkkailtava. Yksi asia on, että kun havainnoiva otos esittää paraikaa tapahtuvia tilanteita eli uutta asiaa, osallistavat uutiskuvat voivat ikään kuin nostaa esittämänsä asiat uusiksi tai uutisarvoiksi. Lisäksi kun uutisjutussa kerrotaan vaikkapa suomalaisten liiallisesta vedenkulutuksesta, ei ole yhtä tai paria paikkaa, tilannetta tai henkilöä, jota kuvata. Silloin toimitus saattaa käyttää esimerkkitapausta. Kriittinen kuvantulkitsija kysyy silloin, millainen osallistava otos on metonyymisesti valittu edustamaan koko laaja-alaista ilmiötä tai tapahtumaa. Toisinaan käytetään käänteistä taktiikkaa (esim. esitetään vesipihi perhe), jotta uutisvalokuva ei johdattele mieltämään negatiivista uutista esimerkiksi tietyn ihmisryhmän ongelmaksi. Viime kädessä paradigmaattisilta ja syntagmaattisilta valinnoilta ei silti voi koskaan välttyä osallistavissa eikä havainnoivissa uutiskuvissa - ja valokuva on aina metonymia.

Havainnoivan ja osallistavan moodin uutiskuvien erottaminen on sikälikin avartavaa, että nämä moodit kytkeytyvät usein eri aiheiden kuvaukseen pitkälti vastaavasti kuin kovat ja pehmeät uutiskirjoitukset. Keskeisiksi perusteiksi, joilla kovat uutiset on eriytetty pehmeistä, on monesti ehdotettu uutistuotantoon liittyviä erilaisia ajallisia rytmejä ja erilaisia aiheita tai sisältöjä (esim. Tuchman 1978, 47-51). Carsten Reinemann ja kumppanit (2012, 222-226) esittävät, että vaikka kovista ja pehmeistä uutisista on kirjoitettu yli kolmekymmentä vuotta, nämä termit on usein määritelty epätarkasti (myös Boczkowski 2009). He erittelevät vuodesta 1990 alkaen englanniksi julkaistuja tutkimuksia laajalti ja toteavat, että kova-pehmeä-jaottelussa on itse asiassa käytetty viittä ulottuvuutta: uutisten 1) aihe / tapahtumat, 2) tyyli, 3) tuotanto, 4) vastaanotto, 5) fokus (esim. julkinen vs. privaatti kehys) (myös Kunelius 1993). Ylivoimaisesti keskeisen jaottelun peruste tutkimuksissa on ollut aihe. Reinemann ja kumppanit $(2012,231)$ kritisoivat tätä, koska on usein epäselvää, miksi jokin aihe ymmärretään kovaksi tai pehmeäksi. He huomaavat tosin monien tutkijoiden tarkoittavan aiheella oikeastaan uutisen yhteiskunnallista relevanssia tai informaatio/viihteellisyys-arvoa. 
Erehdys piileekin siinä, että jokin aihe on etukäteen nimetty kovaksi tai pehmeäksi, sillä esimerkiksi näennäisesti kovat aiheet voidaan kehystää myös viihteellisesti.

Artikkelin johtopäätöksenä ehdotan kahden työkalun tuottamista uutisvalokuvien tarkasteluun ensisijaisesti havainnoivan ja osallistavan moodin pohjalta (vrt. Reinemann ym. 2012, 232-233), sillä näihin usein uutiskuvissa ilmeneviin moodeihin sisältyy siis erilaiset näkemykset siitä, miten dokumentaarisuutta tai tietoa voidaan tuottaa todellisuudesta. Lisäksi puuttumattomuuden ja vuorovaikutteisuuden kuvausperiaatteisiin kytkeytyvät erilaiset kuvattava-valokuvaaja-valtasuhteet. Havainnoiva moodi, varsinkin siihen liittyvät tyylit korostavat siis valokuvan informatiivisuutta ja tärkeyttä. Sitä vastoin osallistavaan moodiin liittyy usein tyylejä, jotka tunnistetaan tyyleiksi ja jotka vihjaavat uutiskuvien kiinnostavuudesta ja lievemmästä uutis- tai totuusarvosta. Koska nämä moodit saattavat hahmottua oppijalle juuri vertailemalla, miten erityyppisiä uutisaiheita on lähestytty, näiden työkalugenrejen avaukseen on hyvä liittää kuvailut tyypillisistä kuvausaiheista.

\section{Osallistava ja performativinen moodi henkilövalokuvissa}

Henkilökuvia otetaan usein haastattelutilanteissa, mikä implikoi vuorovaikutteisuuden periaatetta. Kobré $(2008,81)$ esittää tosin, että journalistiset muotokuvat voivat olla sekä poseerattuja että piilokameraotoksia (ks. myös henkilökuvaesimerkit, Miettinen 1984, 196-199). Uutistapahtumissa puuttumattomuusperiaatteen mukaisesti otettuja ihmisvalokuvia onkin joskus nimetty henkilökuviksi. Kun ihmisiä valokuvataan vuorovaikutteisesti, kuvaaminen on haastavampaa kuin puuttumattomuuden periaatetta käytettäessä. Malli reagoi valokuvaajan persoonaan ja ohjaukseen, mikä näkyy valokuvissa hyvässä ja huonossa. Henkilövalokuvaus vaatii valokuvaajalta peruskuvaustaitojen ohella hyviä sosiaalisia vuorovaikutustaitoja ja kykyä hahmottaa toisen ihmisen persoonan ydin (Kobré 2008, 82-84; Freeland 2007, 105-108). Nähdäkseni siksi sitä arvostetaan piilokameratyyppistä valokuvausta enemmän. Vuorovaikutteisuuden periaate voidaankin käsittää mallin luonnehtimisen ohella toiseksi kriteeriksi määritellä henkilövalokuvan ideaalityyppi.

Henkilövalokuvissa vaihtelee, paljonko mallit voivat osallistua kuvausprosessiin ja missä määrin heillä on siis valtaa valokuviensa syntyyn. Henkilövalokuvissa mallit tietoisesti viestivät itsestään, kun piilokameratyyppinen inmiskuva on vain kuvaajan ja toimituksen viesti yleisöille. Osa henkilökuvista on perinteisten muotokuvavalokuvien tyylisiä ja osa mielikuvituksellisia teoksia. Ensinnäkin monissa henkilökuvissa malli esitetään hänelle tyypillisessä ympäristössä tai neutraaleissa studio-olosuhteissa, eikä niissä käytetä esimerkiksi erikoisia kuvakulmia tai värimaailmoja. Henkilö pukeutuu itselleen tavanmukaisesti ja poseeraa usein muotokuvausperinteen mukaisesti. Näiden valokuvien kuvaustyyliä voinee sanoa näköiseksi tai realistiseksi, mallin tavanomaista ulkonäköä, eleitä ynnä muuta luonnehtiviksi. Tarkemmin ottaen tyyli on sellainen, joka implisiittisesti ajatellaan näköisyyden tai dokumentaarisuuden standardiksi henkilökuvauksessa (myös Newton 2001, 44). 
Henkilövalokuvien malli voi myös olla pukeutunut erikoisesti, esiintyä epätavallisessa asennossa, paikassa tai elehtiä arjesta tai muotokuvausperinteestä poikkeavasti. Kuvaustilanteessa malli esiintyy kameran edessä performatiivisesti valokuvaajan tai omasta aloitteestaan. Yksi Nicholsin (2001, 130-137) moodi onkin performatiivinen. Helke $(2006,89)$ kritisoi, että se on liian laaja ja hämärä moodi. Ajattelen vastaavasti, että valokuvauksessa se on jaettava kahtia. Nicholsin $(2001,131)$ performatiivisen moodin tulkitsen valokuvauksessa tarkoittavan, että valokuvaaja käyttää omaa elämäänsä valokuviensa materiaalina: hän hyödyntää peittelemättä esimerkiksi subjektiivisia kokemuksiaan, muistojaan ja tunteitaan. (Myös Helke 2006, 87-88.) Helken (2006, 90-95) mukaan Nichols ei viittaa performatiivisuudella siihen, että dokumentaareissa kirjaimellisesti esiinnyttäisiin. Hän pitää silti tällaista todellista ja kuviteltua yhdistävää näyteltyä dokumentaaria perusteltuna. Tällaiset elokuvat paljastavat epäautenttisuutensa ja kutsuvat katsojaa eläytymään. Henkilövalokuvista voi havainnoida juuri tämän Helken esittämän kategorian. ${ }^{11}$

Kun Helken mielessä performatiivisia henkilövalokuvia tuotetaan, mallilla saattaa olla paljon enemmän valtaa kuvansa syntyyn kuin näköisissä henkilökuvissa. Niissä kuvaustyyli voi olla mitä tahansa ja kuvissa ilmenevät esineet ja muu rekvisiitta voivat olla kuvausympäristöönsä nähden kovin vieraita. Sitä vastoin näköisissä otoksissa (jos ne eivät ole studiokuvia), mallin luonnehdintaan hyväksytyt esineet ynnä muu näyttävät kuvausympäristöön kuuluvilta. Vaikka performatiiviset henkilövalokuvat saattavat näyttää pelkältä fiktiolta, ne pyrkivät silti luonnehtimaan mallejaan, mutta lähinnä mielikuvallisesti ja hyvin valikoidusti. Mallin osallistumisasteen ja vallankäytön mahdollisuuden sekä dokumentaarisuus-fiktiivisyys-akselin perusteella henkilövalokuvat lienee mielekästä tyypitellä lähinnä kahteen kategoriaan (vrt. Brusila 1997, 91-132), joiden välinen raja on toki liukuva.

Kuvaustyylit ehdottavat myös henkilökuville tiettyjä tulkinta-asemia. Kun näköisissä henkilövalokuvissa tyylit, poseeraukset ja ylipäätään rekvisiitan käyttö on rajoitettua, ne ikään kuin suostuttelevat tulkittavan itsensä informatiivisina tai dokumentaarisina. Näin tapahtuu vielä korostuneemmin ihmistunnistevalokuvissa, joiden kuvaustyylit ovat vieläkin rajoittuneempia. Performatiiviset henkilövalokuvat, jotka voivat olla korostuneen mielikuvituksellisia luomuksia, tunnistetaan sitä vastoin symbolisiksi. Täten ne ehdottavat luentaa kommunikatiivisina, jolloin niiden koetaan ilmentävän totuutta niukemmin. Samalla voi jäädä tiedostamatta niiden kyky suostutella tietyn näkemyksen omaksumiseen välittämiensä mielikuvien sekä herättämiensä tunteiden ja samastumisten kautta (suostuttelun keinoista ks. Mustonen 2000, 46-51).

\section{Työkaluja medialukutaitoon ja sen opetukseen}

Olen koonnut medialukutaidon edistämiseen suunnitellut journalistisen valokuvan työkalugenret pääpiirteissään taulukkoon 1, jonka jälkeen kertaan ne lyhyesti. 


\section{UUTISVALOKUVAT}

- tarkoitus: uutisointi

- dokumentaarisia

\author{
Havainnoiva (kova) uutisvalokuva (suuri uutisarvo) \\ - havainnoiva moodi: puuttumattomuuden kuvausperiaate, usein \\ objektiivisuuden tai autenttisuuden kuvaustyyli \\ - ilmenee tärkeänä tai yleisesti merkittävänä \\ Osallistava (pehmeä) uutisvalokuva (lievä uutisarvo) \\ - osallistava moodi: vuorovaikutteisuuden kuvausperiaate, monia \\ kuvaustyylejä, esim. objektiivisuuden tyyli \\ - ilmenee lähinnä kiinnostavana \\ - usein ns. ihmisläheisiä (human interest)
}

KUVITUSVALOKUVAT (ei uutisarvoa)

- tarkoitus: mielikuvin havainnollistaa asioita ja/tai toimia esim. katseen vangitsijana

- dokumentaarisia tai fiktiivisiä (esim. lavastettuja otoksia, valokuvakollaaseja)

- dokumentaarisissa kuvissa kuvaustyylit ovat rajoittuneita, fiktiivisissä kuvissa vapaita

\section{HENKILÖVALOKUVAT}

(ei välttämättä uutisarvoa)

- tarkoitus:

luonnehtia ihmisiä

\section{Näköinen henkilövalokuva}

- osallistava moodi: vuorovaikutteisuuden kuvausperiaate, usein muotokuvaperinteen kuvaustyylit

\section{Performatiivinen henkilövalokuva}

- vuorovaikutteinen kuvausperiaate liukuu performatiiviseksi esiintymiseksi

- kuvaustyylit vapaita

TUNNISTEVALOKUVAT (ei yleensä uutisarvoa, mutta joskus arvo dokumentin kaltaisena)

- tarkoitus: esimerkiksi henkilön, esineen, eläimen tai paikan identifiointi

- dokumentaarisia

- havainnoiva tai osallistava moodi (puuttumattomuus- ja vuorovaikutteisuusperiaate)

- kuvaustyylit rajoitettuja

Taulukko 1: Journalistisen valokuvan työkalugenret

Aluksi muodostin journalististen otosten funktioiden pohjalta uutis-, kuvitus-, henkilö- ja tunnistevalokuvien genret. Uutisvalokuva on dokumentaarinen otos, joka kertoo äskettäin sattuneesta tapahtumasta tai tietoon saadusta uudesta, tärkeästä, yleisesti merkittävästä tai kiinnostavasta tapahtumasta, ilmiöstä tai henkilöstä ja joka saa uutisarvon (Hall 1984, 174; Kuutti 2006, 241, 243-244 ). Kuvituskuvilla ei sitä vastoin ole uutisarvoa. Niiden tarkoituksena on mielikuvin havainnollistaa asioita tai toimia katseen vangitsijoina tai visuaalisina houkuttimina. Henkilökuvan tehtävänä on erityisesti luonnehtia mallia, kun uutiskuvissa fokus on yleensä tapahtumissa, joihin ihminen liittyy. Semioottisesti ilmaisten ne eroavat merkkien hierarkiassa. Tunnistevalokuvat puolestaan identifioivat esimerkiksi ihmisiä, paikkoja tai esineitä. Ihmistunnistekuvat poikkeavat henkilökuvista sikäli, että niiden tarkoituksena on vain ilmentää tai muistuttaa, miltä joku henkilö näyttää ulkoisesti.

Kehitin edelleen etenkin uutis- ja henkilövalokuvan työkalugenrejä soveltamalla niihin Bill Nicholsin (2001; 1991) dokumentaariseen elokuvaan liittämiä moodeja. Ehdotin uutisvalokuvien analyysiin kahta työkalua kuvissa usein ilmenevien havainnoivan ja osallistavan moodi pohjalta, jotka ensinnäkin ilmentävät erilaisia näkemyksiä siitä, miten dokumentaarisuutta voidaan tuottaa. Toiseksi näihin moodeihin liittyy 
etiikaltaan ja valokuvaaja-kuvattava-valtasuhteiltaan eriävät puuttumattomuuden ja vuorovaikutteisuuden valokuvausperiaatteet. Havainnoivan moodin uutisvalokuvissa kuvaustyylejä on rajoitetusti. Niissä suositaan objektiivisuus- ja autenttisuustyylejä, jotka toimivat visuaalisia vihjeinä uutiskuvien totuudellisuudesta, jopa tärkeydestä. Osallistavan moodin uutisvalokuviin liittyy sitä vastoin usein tyylejä, jotka eivät kätke kuvaajan ja mallin vuorovaikutusta ja jotka siis paljastavat kuvat representaatioiksi. Nämä tyylit vihjaavat valokuvien niukemmasta totuusarvosta ja kiinnostavuudesta. Havainnoivan ja osallistavan moodin uutisvalokuvissa keskitytään usein erilaisiin uutisaiheisiin samansuuntaisesti kuin kovissa ja pehmeissä uutiskirjoituksissa. Liitinkin havainnoivan uutiskuvan ideaalityyppiin sen, että valokuvat tuodaan esille tärkeinä tai yleisesti merkittävinä. Osallistavat uutisvalokuvat ilmentyvät puolestaan lähinnä kiinnostavina ja merkityksiltään yksityisinä tai erityisinä.

Päättelin, että henkilökuvissa käytetään usein vuorovaikutteisuusperiaatetta, jota esitin henkilökuvan ideaalityypin pääkriteeriksi kuvattavan henkilön luonnehtimisen lisäksi. Osassa kuvista tämä periaate venyy tosin mallin performatiiviseksi esiintymiseksi. Lisäksi vaihtelee, missä määrin mallilla on valtaa kuvansa syntyyn. Osa henkilövalokuvista on perinteisten muotokuvien tyylisiä, osa mielikuvituksellisia luomuksia. Ehdotin, että henkilökuvien analysointiin rakennetaan näköisen ja performatiivisen henkilökuvan työkalugenret sen pohjalta, että mallin valta vaikuttaa kuvansa syntyyn vaihtelee ja henkilökuvat asettuvat eri kohtiin dokumentaarisuusfiktiivisyys-akselilla. Lisäksi niissä tyylien käyttö vaihtelee: todenmukaisempaan kerrontaan pyrkivissä henkilökuvissa rajoitutaan lähinnä muotokuvausperinteen tyyleihin, kun todellista ja kuviteltuja yhdistelevissä performatiivisissa otoksissa eri tyylejä käytetään vapaasti. Työkalugenrejä on syytä vielä testata autenttisissa tilanteissa esimerkiksi sen tutkimiseksi, tarvitseeko kuvituskuville rakentaa kaksi työkalua (esim. konstruoidut kuvituskuvat vs. dokumentaariset ja dokudraamat). Samaa voi kysyä tunnistekuvista, joissa ilmenee havainnoiva ja osallistava moodi. Eritoten kuvitusvalokuvien avaus edellyttäisi nähdäkseni muitakin välineitä kuin Nicholsin moodit, siten niiden käsittely jäi tässä tekstissä niukaksi. Myös kuvaustyylien lisätutkimus olisi paikallaan.

Työkalugenrejen kuva-analyysikäytössä ajatus on, että oppija havainnoi tulkittavaa valokuvaa kontekstissaan ja reflektoi sitä suhteessa työkalugenrejen kuvailuihin. Esimerkiksi vertailemalla tulkittavaa otosta kontekstissaan vaikkapa kuvituskuvaan, oppijalle voi hahmottua, että otoksella on uutisarvo - joten se ei ole kuvitusta. Sitten hän voi tarkastella, onko kuvassa havainnoivan tai osallistavan uutisvalokuvan piirteitä. Tämän myötä voi syntyä vaikkapa oivallus, että kuvassa on käytetty objektiivisuuden tyyliä, joka saa otoksen näyttämään piilokameran tuotokselta. Tästä hän saattaa siirtyä pohtimaan valokuvaaja-kuvattava-valtasuhdetta ja miettiä myös kuvan ottamiseen liittyviä eettisiä kysymyksiä. Tämäntyyppisen peilailun tavoitteena ei ole saada tulkittavaa kuvaa lokeroiduksi johonkin genreen. Itse asiassa kaikki elämismaailmoissa esiintyvät valokuvat eivät edes istu tässä tekstissä luotuihin tyyppeihin, sillä työkalugenret ovat ideaalityyppejä. Genrejen käytön tavoitteena on, että peilatessaan tulkittava valokuvaa työkalugenreihin tulkitsija tulee kiinnit- 
täneeksi huomiota kuvan ehdottamaan tulkinta-asemaan ja kriittisiin piirteisiin. Luovaan työskentelyyn pohjaavassa opetuksessa työkalugenret voivat toimia vaikkapa oppijoiden omien tyyppien rakentelun lähtökohtina. Työkalugenrejä on mahdollista edelleen kehittää. Lisäksi journalististen valokuvien analyysiin on mielekästä rakentaa myös valokuvien ja tekstien suhteisiin keskittyvä tulkinta-apparaatti, joka voi osittain muodostua päällekkäiseksi tässä esitetyn genremallin kanssa.

Pyrkimys nimetä tulkittava valokuva johonkin genreen voi olla ongelmallinen siksi, että joku oppija voi kokea valokuvan vaikkapa vain kuvaavan jotakin tapahtumaa, kun toinen tulkitsija kokee sen luonnehtivan inmistä. Olennaista valokuvan peilailussa eri työkalugenreihin on, että oppijan omakohtaisten kokemusten ja tulkintojen perustat avautuvat. Rakennettu genremalli on tarkoitettu työkaluksi David Buckinghamin (2003, 13-14) kuvailemaan kriittiseen medialukutaitoon, jossa kyse ei ole kyse johonkin sovittuun, kuten opettajan toivomaan tulkintaan pääsystä. Käsitän valokuvien kriittisen tulkinnan omien valokuvakokemusten tiedostamiseksi ja henkilökohtaisten merkityksenantojen sosiokulttuuristen perustojen tarkasteluksi ja arvioinniksi. Samalla se on ymmärrystä siitä, millaisia sosiokulttuurisia konstruktioita valokuvat ovat. (Myös emt., 71, 186.) Kriittisen tulkinnan arvona on, että yksilölle muodostuu edellytyksiä oivaltaa, miten häntä voidaan johdattaa tiettyihin merkityksenantoihin, ja että hänelle syntyy kyky haastaa näitä merkityksiä. Samalla kehittyy edellytyksiä keskustella toisten ihmisten kanssa valokuvien sisällöistä rakentavassa hengessä ja ottaa valokuvia intentionaalisesti (myös esim. emt., 13, 84; Kupiainen \& Sintonen 2009, 100, 141).

\section{Viitteet}

1 Genreä kutsutaan suomeksi myös lajityypiksi (esim. Herkman 2007, 106). Käytän näitä termejä synonyymeina, vaikka niille on ehdotettu eriäviäkin merkityksiä (ks. Ridell 2006, 211). Lisäksi saatan lyhentää sanan lajityyppi yksinkertaisesti tyypiksi.

2 Kriittisellä viittaan Jürgen Habermasin $(1976,134-137)$ emansipatoriseen tiedonintressiin, joka liittyy valtaan ja jossa tiedon tehtäväksi käsitetään vapauttaa yksilö perinteen ohjaamasta ajattelusta ja toiminnasta.

3 Kuvitusvalokuvia kutsutaan toisinaan myös symbolikuviksi (esim. Miettinen 1984, 201).

4 Malli omistaa yleensä muotokuvansa tai hän luovuttaa sen eteenpäin, kun henkilövalokuvan omistaa useimmiten mediatalo ja/tai valokuvaaja. Vallankäyttöön liittyy myös, että muotokuvan mallin yleensä viime kädessä hyväksyy jonkin otoksen muotokuvakseen.

5 Tarkastellessani lehdistä kuvareportaaseja (muista nimityksistä esim. Salo 2000, 82), huomaan, että niissä esiintyy uutis-, henkilö-, kuvitus- ja tunnistevalokuvia. Reportaasivalokuvat eivät genreydykään $y$ ksittäisen valokuvan tasolla itsenäiseksi tyypiksi ainakaan suomalaisessa nykykulttuurissa. Valokuvareportaasit voivat silti olla tyypiteltävissä kuvakokonaisuustyypeiksi (ks. emt.).

6 Uutisvalokuvissa voi nähdäkseni ilmetä myös esim. selittävä ja refleksiivinen moodi (ks. Nichols 1991, 105-109, 125-130). Kuvareportaaseista voi tavoittaa esim. runollisen moodin.

7 Uutiskriteerit voidaan Kuutin $(2006,244)$ mukaan myös jaotella julkaistavien asioiden tärkeyden, kiinnostavuuden ja tarkoituksenmukaisuuden pohjalta. Tärkeys viittaa laajaa ihmisjoukkoa todennäköisesti kiinnostavaan asiaan (ajankohtaisuus, läheisyys, tapahtuman näyttävyys ja seuraukset). 
8 Tulkitsen, että Kuutin $(2006,244)$ mukaan kiinnostavuuden uutiskriteeriin liittyy, että uutinen herättää vastaanottajassa mm. henkilökohtaista mielenkiintoa tai sympatiaa.

9 Ajattelen, että on erheellistä pitää kameratonta maailmaa luonnollisempana, jos kamera on siinä silti läsnä. On luontevaa, että valokuvattava poseeraa, kun hän tiedostaa muuttuvansa näkymäksi. Poseeraus on vallan ja kontrollin osittaista haltuunottoa (myös Newton 2001, 35).

10 Valokuvausta rajoittavat toki silti koti- ja julkisrauhaa koskevat lait.

11 Performatiivisiin henkilökuviin voi liittyä myös esim. refleksiivinen moodi (ks. Nichols 1991, 125-130).

\section{Kirjallisuus}

Altman, Rick (2002 [1999]). Elokuva ja genre. Suom. K. \& S. Laine. Tampere: Vastapaino.

Bate, David (2009). Photography. The Key Concepts. Oxford: Berg.

Bell, Allan (1991). The Language of News Media. Oxford: Basil Blackwell.

Boczkowski, Pablo J. (2009). Rethinking hard and soft news production. Journal of Communication 59: 1, 98-116.

Bright, Susan (2005). Art photography now. London: Thames \& Hudson.

Brighton, Paul \& Foy, Dennis (2007). News values. London: SAGE.

Brusila, Riitta (1997). Realismista fiktioon: Visuaalisuus ja suomalaiset aikakauslehdet. Acta Universitatis Tamperensis 577. Tampere: Tampereen yliopisto.

Buckingham, David (2003). Media education. Literacy, learning and contemporary culture. Cambridge: Polity.

Edelson, Daniel C. (2002). Design research: What we can learn when we engage in design. The Journal of the learning sciences 11: 1, 105-121.

Evans, Harold (1978). Pictures on a page: Photo-journalism, graphics and picture editing. London: Heinemann.

Feuer, Jane (1987). Genre study and Television. Teoksessa: Allen, Robert C. (toim.). Channels of discourse. Television and contemporary criticism. London: Routledge, 138-16o.

Fiske, John (1992 [1990]). Merkkien kieli. Johdatus viestinnän tutkimiseen. Suom. toim. V. Pietilä; R. Suikkanen \& T. Uusitupa. Tampere: Vastapaino.

Freeland, Cynthia (2007). Portraits in painting and photography. Philosophical Studies, 135: 1, 95-109.

Goffman, Erving (1986 [1974]). Frame analysis. Boston: Northeastern University Press.

Habermas, Jürgen (1976 [1968]). Tieto ja intressi. Suom. P. Löppönen. Teoksessa: Tuomela, Raimo \& Patoluoto, Ilkka (toim.). Yhteiskuntatieteiden filosofiset perusteet, osa I. Helsinki: Gaudeamus, 118-141.

Hall, Stuart (1984 [1972]). Uutiskuvien määräytymisprosessi. Suom. J. Tainio. Teoksessa: Lintunen, Martti (toim.). Kuvista sanoin 2. Helsinki: Suomen valokuvataiteen museon säätiö, 139-19o.

Harris, Christopher R. (2002). Documentary Assignments; Manipulated Assignments. Teoksessa: Lester, Paul Martin \& Harris, Christopher R. Visual journalism. A guide for new media professionals. Boston: Allyn and Bacon, 87-132.

Heikkilä, Elina (2006). Kuvan ja tekstin välissä. Kuvateksti uutiskuvan ja lehtijutun elementtinä. Helsinki: Suomalaisen Kirjallisuuden Seura, toimituksia 1065.

Heikkinen, Hannu L. T.; Kontinen, Tiina \& Häkkinen, Päivi (2006). Toiminnan tutkimisen suuntaukset. Teoksessa: Heikkinen, Hannu L. T.; Rovio, Esa \& Syrjälä, Leena (toim.). Toiminnasta tietoon. Toimintatutkimuksen menetelmät ja lähestymistavat. Helsinki: Kansanvalitusseura, 39-76.

Helke, Susanna (2006). Nanookin jälki: Tyyli ja metodi dokumentaarisen ja fiktiivisen elokuvan rajalla. Taideteollisen korkeakoulun julkaisusarja A 65. Helsinki: Taideteollinen korkeakoulu.

Herkman, Juha (2007). Kriittinen mediakasvatus. Tampere: Vastapaino.

Huang, Edgar Shaohua (2001). Readers' perception of digital alteration in photojournalism. Journalism Q Communication Monographs, 3: 3, 147-182.

Karvonen, Erkki (2000). Tulkintakehys (frame) ja kehystäminen. Tiedotustutkimus 23: 2, 74-84.

Kobré, Kenneth (2008). Photojournalism: The professionals' approach. 6th ed. Oxford: Focal Press.

Knox, John S. (2009). Visual minimalism in hard news: thumbnail faces on the smh home page. Social Semiotics 19: 2, 165-189.

Kress, Gunther \& Theo van Leeuwen (1996). Reading images: The grammar of visual design. London: Routledge. 
Kunelius, Risto (1993). Uskottavuuden anatomia: Kova uutinen, genre ja kansalainen. Tiedotustutkimus 16 : 2, 33-45.

Kupiainen, Reijo \& Sintonen, Sara (2009). Medialukutaidot, osallisuus, mediakasvatus. Helsinki: Palmenia, Helsinki University Press.

Kuutti, Heikki (2006). Uusi mediasanasto. Jyväskylä: Atena.

Lester, Paul (1991). Photojournalism: An ethical approach. Hillsdale: Lawrence Erlbaum.

Loosley, Arthur E. (1970). The business of photojournalism. New York: Amphoto.

Mayer, Richard H. (1999). Designing instruction for constructivist learning. Teoksessa: Reigeluth, Charles M. (toim.). Instructional-design theories and models. A new paradigm of instructional theory. Volume II. Mahwah: Lawrence Erlbaum, 142-159.

Mendelson, Andrew (2004). Slice-of-life moments as visual "truth": Norman Rockwell, feature photography, and american values in pictorial journalism. Journalism History, 29: 4, 166-178.

Miettinen, Jorma (1984). Toimitustyö: Journalistiksi suunnistavan oppikirja. Helsinki: Gaudeamus.

Mustonen, Anu (2000). Mediapsykologia. Helsinki: WsoY.

Mäenpää, Jenni (2008). Muokkausta ja manipulaatiota. Digitaalisen kuvankäsittelyn rajat suomalaisissa sanoma- ja aikakauslehdissä. Tampere: Tampere University Press.

Männistö, Anssi (1999). Islam länsimaisessa hegemonisessa diskurssissa. Myyttis-ideologinen ja kuvaanalyyttinen näkökulma sivilisaatioiden kohtaamiseen. Tampere: Rauhan- ja konfliktintutkimuskeskus TAPRI, Tutkimuksia no. 87.

Newton, Julianne H. (2001). The burden of visual truth: The role of photojournalism in mediating reality. Mahwah: Lawrence Erlbaum.

Nichols, Bill (1991). Representing reality: Issues and concepts in documentary. Bloomington: Indiana University Press.

Nichols, Bill (2001). Introduction to documentary. Bloomington: Indiana University Press.

Palin, Tutta (1993). Muotokuvan problematiikka. Synteesi 12: 2, 11-27.

Pienimäki, Mari (2011). Mitä inmettä - valokuvissako lajityyppejä? Teoksessa: Kotilainen, Sirkku; Urpo Kovala \& Erkki Vainikkala (toim.). Media, kasvatus ja kulttuurin kierto. Nykykulttuurin tutkimuskeskuksen julkaisuja 106. Jyväskylä: Jyväskylän yliopisto, 151-176. Saatavilla: http://urn.fi/ URN:ISBN:978-951-39-4655-5

Poecke, Luc Van (1989). Uutisen tekemisen myytit ja riitit: Kovat versus pehmeät uutiset: Tosiasioiden pyhyydestä ja kommenttien vapaudesta. Tiedotustutkimus 12: 1, 4-28.

Potter, W. James (2004). Theory of media literacy. A cognitive approach. Thousand Oaks: Sage.

Reaves, Shiela (1995). The vulnerable image. Categories of photos as predictor of digital manipulation. Journalism Q Mass Communication Quaterly, 72: 3, 706-715.

Reinemann, Carsten; Stanyer, James; Scherr, Sebastian \& Legnante, Guido (2012). Hard and soft news: A review of concepts, operationalizations and key findings. Journalism 13: 2, 221-239.

Ridell, Seija (2006). Genre ja mediatutkimus. Teoksessa: Mäntynen, Anne; Shore, Susanna \& Solin, Anna (toim.). Genre - tekstilaji. Helsinki: Suomen Kirjallisuuden Seura, 184-213.

Rosler, Martha (2000). Dokumentarismin jälkeen? Suom. P. Sivenius. Teoksessa: Raatikainen, Riitta (toim.). Photo.doc. Dokumentteja dokumentarismista. Musta taide, nro 1, 12-22.

Salo, Merja (2000). Imageware. Kuvajournalismi mediafuusiossa. Taideteollisen korkeakoulun julkaisu B 59. Jyväskylä: Gummerus.

Tuchman, Gaye (1978). Making news. A study in the construction of reality. New York: The Free Press.

Tuori, Santeri (2001). Vallan kuva: Valokuva kontrollipolitiikan välineenä. Pieni valokuvakirjasto 3. Helsinki: Suomen valokuvataiteen museo \& Musta taide. 